\title{
Risks in the construction of houses for the disabled and the elderly
}

\author{
Svetlana Sheina ${ }^{1}$, Artem Shvets $^{1}$, and Elena Gorbaneva ${ }^{2 *}$ \\ ${ }^{1}$ Don State Technical University, 344022, Rostov-on-Don, Russia \\ ${ }^{2}$ Voronezh State Technical University, 394006, Voronezh, Russia
}

\begin{abstract}
The paper presents possible problems in the construction of houses for the disabled and the elderly. The relevance of the construction of these real estate objects and the consideration of this issue of the article is displayed. The possible main hazards during capital construction are given. The economic aspect of the construction issue, its nuances, and methodology are considered in detail using the examples of two objects of houses for the disabled and the elderly of various forms of ownership. For each of the potential planned objects, the necessary data collection was performed, calculations of possible income based on the activities of the house for the disabled and the elderly, expenses, both at the construction stage and at the exploitation stage, which are shown in this article. Graphically, the result of the comparative analysis of the two objects for economic efficiency is shown and the conclusion is made about the choice of the most profitable form for performing specific tasks.
\end{abstract}

\section{Introduction}

Nowadays, the aging of the nation around the world is an actual problem. According to the UN report 2019 Revision of World Population Prospects, the population over 65 years of age in 2050 will be 16\%, up from 6\% in 2019 [1]. To ensure a decent standard of living for the elderly and disabled, it is necessary to build high-quality homes for them, corresponding and using modern technologies and requirements. For example, as such technologies can be chosen so-called green technologies [2]. Regardless of the chosen construction methods, a teach of its stages there are possible risks that can lead to various difficulties during the construction of a building/structure or during its further exploitation.

\section{Methods and materials}

In capital construction, the following main risks are distinguished:

1) lack of information about the object at the pre-project stage;

2) changing solutions during the design stage;

3) exceeding the original estimated cost of the object;

4) ensuring the safety of the facility at all stages of exploitation;

\footnotetext{
*Corresponding author:egorbaneva@vgasu.vrn.ru
} 
5) with an objective assessment of the object's condition. [3]

In our research, we have considered the economic aspect of risks - profitability. Our goal was to estimate and calculate the economic efficiency of homes for the disabled and the elderly. To calculate economic efficiency means to determine and display how effective the organization's activities and the realization of a particular project are. The basis for calculating this parameter is the ratio of the result of work (income) and the costs of obtaining it. [4]

Depending on the form of ownership, the economic efficiency can be different. In our research, two forms were considered:

1) public;

2) public-private partnership.

The public form implies that all the costs of construction, exploitation and other costs are borne by the government. In a public-private partnership, public authorities and private businesses interact on the principle of sharing risks between the participants, fixing the obligations and conditions for the implementation of the project in the agreement. $[5,6]$ To determine economic efficiency for different forms of ownership and then compare them, we need to know: possible income and costs for a home for the disabled and the elderly. For a public-private partnership, the economic efficiency will be calculated by the private person, who makes the main investment in construction. Its proportion of both costs and incomes will be $66,7 \%$; the government's proportion will be $33,3 \%$.

\subsection{Article of incomes for houses for the disabled and the elderly}

In this article, we will consider the income during the exploitation of the real estate. The income will mainly consist of the main activity of providing a place of residence, medical services and other possible income.

\subsubsection{Incomes from main activities}

The public houses for the disabled and the elderly provides 200 beds, the public-private120 beds. Types and possible options of services vary depending on the form of ownership. In a public house for the disabled and the elderly, a set of standard services is provided that are approximately the same for everyone, while in a public-private investor, that is, a private person, is able to provide various packages that differ in a set of services, comfort and, accordingly, cost. Also, in a public-private partnership, service packages are divided into public and commercial. We will demonstrate all the services in Figure 1.

\begin{tabular}{|c|c|c|c|}
\hline $\begin{array}{c}\text { Form of } \\
\text { ownership }\end{array}$ & $\begin{array}{c}\text { Name of } \\
\text { service } \\
\text { packages }\end{array}$ & Type of service & $\begin{array}{c}\text { Cost of } \\
\text { package per } \\
\text { month., rub. }\end{array}$ \\
\hline Public & Public & Public & 32160 \\
\hline \multirow{4}{*}{$\begin{array}{c}\text { Public-private } \\
\text { partnership }\end{array}$} & Public & Public & 18210 \\
\cline { 2 - 4 } & Public care & Public & 18210 \\
\cline { 2 - 4 } & Optimal & Commercial & 45000 \\
\cline { 2 - 4 } & Comfort & Commercial & 65000 \\
\cline { 2 - 4 } & Care + & Commercial & 73000 \\
\hline
\end{tabular}

Fig. 1. Packages of services depending on the form of ownership. 
Next, we needed to calculate the income from these packages, taking into account all operating costs. This takes three stages:

1) Calculation of potential gross income (PGI), describing the maximum possible income;

2) Calculation of the actual gross income (AGI), in which losses from partial non-use are subtracted from PGI;

3) Calculation of net operating income (NOI), where the operating costs (OC) allocated to the implementation of this activity are subtracted from AGI. [7]

Losses may occur due to incomplete use of a particular service, incomplete fullness of beds. Also, in accordance with №. 442-FZ "On the basics of social services for citizens in the Russian Federation", it is established that on state support, a resident pays for accommodation in the amount of $75 \%$ of his pension. At the same time, if he is responsible for a dependent, the payment is reduced to $50 \%$ for one dependent, $42 \%$ for two, $25 \%$ for three or more [8]. Operating costs - the cost of providing a service, that is, for the purchase of certain equipment, medicines, inventory, and more. We have made all the calculations for the definition of the NOI, they are shown in Figure 2.

\begin{tabular}{|c|c|c|c|c|c|c|c|c|}
\hline $\begin{array}{c}\text { Form of } \\
\text { ownership }\end{array}$ & $\begin{array}{c}\text { Name of } \\
\text { service } \\
\text { packages }\end{array}$ & $\begin{array}{l}\text { Amount of } \\
\text { beds/ total }\end{array}$ & $\begin{array}{c}\text { Ratio of } \\
\text { people with } \\
\text { dependents: } \\
0 / 1 / 2 / 3 \& \\
\text { more }\end{array}$ & $\begin{array}{c}\text { PGI, } \\
\text { thousand } \\
\text { rub. }\end{array}$ & $\begin{array}{c}\text { AGI, } \\
\text { thousand } \\
\text { rub. }\end{array}$ & $\begin{array}{c}\text { OC, } \\
\text { thousand } \\
\text { rub. }\end{array}$ & $\begin{array}{c}\text { NOI, } \\
\text { thousand } \\
\text { rub. }\end{array}$ & $\begin{array}{c}\text { Total NOI, } \\
\text { thousand } \\
\text { rub. }\end{array}$ \\
\hline Public & Public & $200 / 200$ & $\begin{array}{c}130 / 40 / 15 / 1 \\
5\end{array}$ & 77184 & 57875,26 & 37263,1 & 20612,16 & 20612,16 \\
\hline \multirow{5}{*}{$\begin{array}{c}\text { Public- } \\
\text { private } \\
\text { partnership }\end{array}$} & Publif & 0 & 20/7/1/- & 4594,8 & 8 & 788,85 & 3116,73 & \multirow{5}{*}{48263,13} \\
\hline & Public & $12 / 120$ & $5 / 4 / 2 / 1$ & 2721,6 & 1769,04 & 382,02 & 1387,02 & \\
\hline & Optimal & $40 / 120$ & - & 22140 & 18900 & 2307,16 & 16592,84 & \\
\hline & Comfort & $12 / 120$ & - & 11520 & 9600 & 1425,25 & 8174,75 & \\
\hline & Care + & $28 / 120$ & - & 24528 & 21024 & 2032,21 & 18991,79 & \\
\hline
\end{tabular}

Fig. 2.Net operating income for every service packages.

\subsubsection{Incomes from extra activities}

In addition to the main income, there may be extra ones. Depending on the form of ownership, they differ. In a public-private partnership, additional commercial services that are not included in the main service packages can be organized at the initiative of the investor. For these additional services, he will be responsible, organize them and, accordingly, receive income from them. Public houses for the disabled and the elderly are very limited in extra income. In that way the only income can be the work of the residents.

The following additional sources of income will be used in our houses for the disabled and the elderly:

1) State - sale of knitted products made by residents;

2) Public-private partnership - physical therapy classes, a complex of massage procedures, systematic monitoring of residents to identify deviations in their health status.

The method of calculating income corresponds to the method that was used for the main activity. The completed calculations are shown in Figure 3. 


\begin{tabular}{|c|c|c|c|c|c|c|}
\hline $\begin{array}{c}\text { Form of } \\
\text { ownership }\end{array}$ & $\begin{array}{c}\text { Name of } \\
\text { extra } \\
\text { activity }\end{array}$ & $\begin{array}{c}\text { PGI, } \\
\text { thousand } \\
\text { rub. }\end{array}$ & $\begin{array}{c}\text { AGI, } \\
\text { thousand } \\
\text { rub. }\end{array}$ & $\begin{array}{c}\text { OC, } \\
\text { thousand } \\
\text { rub. }\end{array}$ & $\begin{array}{c}\text { NOI, } \\
\text { thousand } \\
\text { rub. }\end{array}$ & $\begin{array}{c}\text { Total NOI, } \\
\text { thousand } \\
\text { rub. }\end{array}$ \\
\hline \multirow{2}{*}{ Public } & $\begin{array}{c}\text { Knitted } \\
\text { products }\end{array}$ & 19440 & 7146 & 2688,5 & 4457,5 & 4457,5 \\
\hline \multirow{2}{*}{$\begin{array}{c}\text { Public- } \\
\text { private }\end{array}$} & $\begin{array}{c}\text { Physical } \\
\text { therapy } \\
\text { plasses }\end{array}$ & 12288 & 10444,8 & 300 & 10144,8 & \\
\cline { 2 - 6 } & $\begin{array}{c}\text { Massage } \\
\text { procedures }\end{array}$ & 20160 & 16992 & 480 & 16512 & \multirow{2}{*}{38300,3} \\
\cline { 2 - 6 } & $\begin{array}{c}\text { Systematic } \\
\text { monitoring }\end{array}$ & 12960 & 11664 & 20,5 & 11643,5 & \\
\hline
\end{tabular}

Fig. 3. Net operating income for extra activity.

\subsection{Article of costs for houses for the disabled and the elderly}

Costs for our houses for disabled and the elderly will consist initially of the estimated cost of construction, then, during exploitation, of payments for utilities, salaries of employees, and the provision of residents.

\subsubsection{Estimated cost of construction}

The construction of any real estate object is impossible without the production of certain works on the construction of the building. All works and their cost should be justified on the basis of the estimated documentation. With the help of the estimated cost, the capital investments are formed for the necessary realization of the construction project. The estimated cost includes the costs of construction, installation works, purchase of necessary equipment, and other expenses. [9]

The estimates of our two examined houses for the disabled and the elderly were made in the federal uniform rates of basic prices on 01.01.2000. To determine the actual cost of construction, operations were performed to transfer the base prices using special transfer coefficients. The final cost of construction is shown in Figure 4.

\begin{tabular}{|c|c|c|c|c|c|}
\hline $\begin{array}{c}\text { Form of } \\
\text { ownership }\end{array}$ & $\begin{array}{c}\text { Construction } \\
\text { works, thousand } \\
\text { rub. }\end{array}$ & $\begin{array}{c}\text { Installation } \\
\text { works, } \\
\text { thousand rub. }\end{array}$ & $\begin{array}{c}\text { Equipment, } \\
\text { furniture and } \\
\text { inventory, } \\
\text { thousand rub. }\end{array}$ & $\begin{array}{c}\text { Other } \\
\text { expenses, } \\
\text { thousand rub. }\end{array}$ & $\begin{array}{c}\text { Total cost, } \\
\text { thousand rub. }\end{array}$ \\
\hline Public & 112925,346 & 44507,175 & 152243,061 & 698,313 & 310373,895 \\
\hline $\begin{array}{c}\text { Public- } \\
\text { private } \\
\text { partnership }\end{array}$ & 154708,5149 & 60975,141 & 208574,06 & 956,694 & 425214,41 \\
\hline
\end{tabular}

Fig. 4. Estimated cost of construction. 


\subsubsection{Exploitation costs}

After the construction of the house for the disabled and the elderly and its start of exploitation, it begins to provide medical services and accommodation. At the same time, the residents are cared for by the staff of the house for the disabled and the elderly, resources are used (water, electricity, etc.). All this requires financial investments: employees need to be paid with salaries, for utilities - to pay bills. [10,11]

The staff headquarters can vary - it is formed according to a regulatory act created by the regional government, and is selected depending on the capacity of the home for the disabled and the elderly. To determine the total costs in this area, a list of employees and their salary rates is created. According to this, the public house for the disabled and the elderly for 200 people has 87 employees; the public-private house for 120 people has 84 employees.

Approximate utility costs are recorded in the passport of the object. Therefore, for the preliminary calculation of expenses, it is necessary to use this data and, in accordance with the tariffs, transfer into money. Adding up all the costs (cold, hot water supply, sanitation, electricity, heating, solid household waste), we get the total annual cost of utilities.

The calculations are shown in Figure 5.

\begin{tabular}{|c|c|c|c|}
\hline $\begin{array}{c}\text { Form of } \\
\text { ownership }\end{array}$ & $\begin{array}{c}\text { Staff } \\
\text { salaries, } \\
\text { thousand } \\
\text { rub. }\end{array}$ & $\begin{array}{c}\text { Payments } \\
\text { for } \\
\text { utilities, } \\
\text { thousand } \\
\text { rub. }\end{array}$ & $\begin{array}{c}\text { Total } \\
\text { exploitation } \\
\text { costs, } \\
\text { thousand } \\
\text { rub. }\end{array}$ \\
\hline Public & 18366,564 & 8542,759 & 26909,323 \\
\hline $\begin{array}{c}\text { Public- } \\
\text { private } \\
\text { partnership }\end{array}$ & 13088 & 7756,95 & 20844,95 \\
\hline
\end{tabular}

Fig. 5. Exploitation costs.

\section{Results and discussion}

After collecting all the necessary data, we can determine the net discounted income. After making the necessary calculations with income and costs, using discount coefficients and considering inflation, we build curves that show the movement of cash flow, starting from construction, continuing during operation [12]. They are shown in Figure 6 and Figure 7.

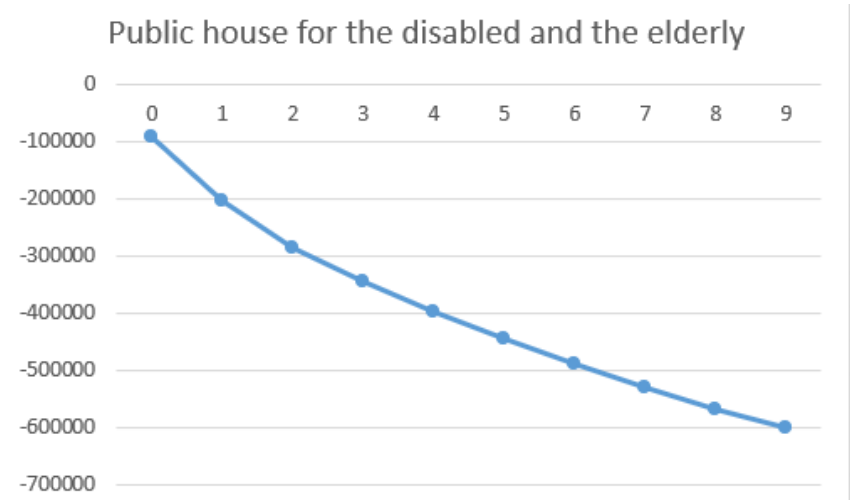

Fig. 6. Curve of the net discounted income for public houses for disabled and the elderly. 


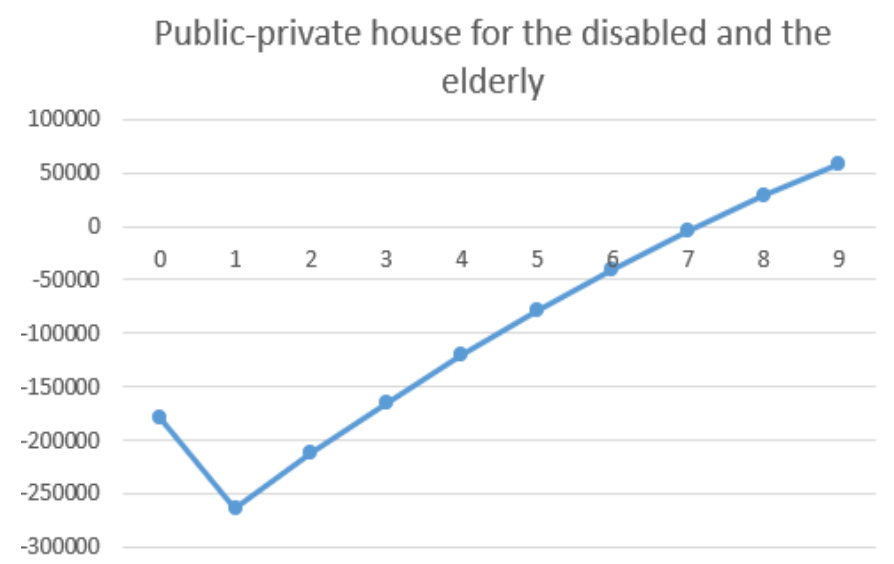

Fig. 7. Curve of the net discounted income for public-private house for disabled and the elderly.

According to the constructed curves, we observe that the public house for the disabled and the elderly is unprofitable, with each period the loss only increases, which means that the costs significantly exceed the possible income. However, a public-private house for the disabled and the elderly has the opportunity to bring profit to the investor. At the beginning, during the construction period, unprofitability is unavoidable, since there are no sources of income; as time passes, during exploitation, income begins to exceed costs, and eventually leads the investor to profit. After an additional calculation, the payback period for that a public-private house for the disabled and the elderly will be 8 years and 1 month. $[13,14,15]$

\section{Conclusions}

The risks associated with economic efficiency and profitability are unavoidable. After analysing two public and public-private houses for the disabled and the elderly, there are noticeable differences in profitability. Income for an investor in a public-private partnership is its fundamental goal. However, for the state form of ownership, profit is not the main goal; for them, the most important indicator is the social effect, that is, the public benefit that the implementation of this project brings, and the compliance of the results of its economic activity with the main goals and needs of society and the individual.

\section{References}

1. Report of the United Nations population estimates and projections, 26 (2019)

2. A. Shvets, S. Sheina, Application of green technologies in the construction of homes for the disabled and the elderly, Don State Technical University, Rostov n/Don (2020)

3. S. Bogachev, A. Shkolnikov, R. Rozentul, N. Klimova, Construction Risks and Means of Their Minimization, Construction Sciences, 1, 88-92 (2015)

4. L. Tesluk, A. Rumyantseva, Evaluation of the efficiency of the investment project, Ural Federal University, Yekaterinburg, 34-37 (2014)

5. A. Kuznechenkova, A. Makeenkov, Ways to improve the efficiency of public administration, System technologies, 26, $43-46$ (2018)

6. V.Varnavskij, Public-private partnership: some questions of theory and practice, World economy and international relations, 9, 41-50 (2011) 
7. N. Mirzoyan, Real property value management, Modern competition, 2, 93-109 (2007)

8. V. Shayhatdinov, Problems of the Russian System of Social Services in the Context of the Federal Law No. 442-FZ, Russian Law: Education, Practice, Science, 6, 92-99 (2017)

9. N. Klipina, A. Buravleva, R. Abakumov, Estimated cost as a basis for pricing in construction, Innovative science, 4, 103-106 (2017)

10. V. Sadim, Yu. Batrakova, S. Ropotan, Salary: modern view of accounting and control, Problems of economics and management, 6, 96-99 (2015)

11. L. Shagiakhmetova, The concept and types of utilities, Current problems of economics and law, 2, 208-210 (2011)

12. G. Grafova, Net income and net discounted income - indicators for evaluating the effectiveness of an investment project, Innovations, 4, 113-115 (2006)

13. A. Kuznetsov, Analysis of the payback period of investment projects, Vestnikuniversiteta, 18, 45-49 (2013)

14. E. Sindyashkina, Questions of assessing the types of social effect in the implementation of investment projects, Problems of forecasting, 1, 140-147 (2010)

15. A. Salosin, O. Gamayunova, A.Mottaeva, EMMFT 2019, IOP Publishing, 1614 (2020) 012028, doi:10.1088/1742-6596/1614/1/012028 